\title{
Effect of Duck Feet Gelatin Concentration on Physicochemical, Textural, and Sensory Properties of Duck Meat Jellies
}

\author{
Hyun-Wook Kim, Jae-Hyun Park, Eui-Joo Yeo, Ko-Eun Hwang, Dong-Heon Song, Yong-Jae Kim, \\ Youn-Kyung Ham, Tae-Jun Jeong, Yun-Sang Choi, and Cheon-Jei Kim* \\ Department of Food Science and Biotechnology of Animal Resources, Konkuk University, Seoul 143-701, Korea
}

\begin{abstract}
This study was conducted to determine the effect of duck feet gelatin concentration on the physicochemical, textural and sensory properties of duck meat jellies. Duck feet gelatin was prepared with acidic swelling and hot water extraction. In this study, four duck meat jellies were formulated with $3,4,5$, and $6 \%$ duck feet gelatin, respectively. In the preliminary experiment, the increase in duck feet gelatin ranged from 5 to $20 \%$, resulting in a significant $(p<0.001)$ increase in the color score, but a decline in the hardness and dispersibility satisfaction scores. An increase in the added amount of duck feet gelatin contributed to decreased lightness and increased protein content in duck meat jellies. Regarding the textural properties, increase in the added amount of duck feet gelatin highly correlated with the hardness in the center $\left(p<0.01, R^{2}=0.91\right)$, and edge $\left(p<0.01, R^{2}=0.89\right)$, of duck meat jellies. Meanwhile, the increase in duck feet gelatin decreased the score for textural satisfaction; duck meat jellies containing $6 \%$ duck feet gelatin had a significantly lower textural satisfaction score, than those containing 3\% duck feet gelatin $(p<0.05)$. Furthermore, a significant difference in the overall acceptance of duck meat jellies formulated with $5 \%$ duck feet gelatin was observed, as compared to those prepared with $3 \%$ duck feet gelatin. Therefore, this study suggested that duck feet gelatin is a useful ingredient for manufacturing cold-cut meat products. In consideration of the sensory acceptance, the optimal level of duck feet gelatin in duck meat jellies was determined to be $5 \%$.
\end{abstract}

Keywords: cold-cut meat product, duck feet gelatin, meat jelly, restructured meat product

\section{Introduction}

Restructuring technology, which is conducted to manufacture restructured meat products, is a useful method to improve the value of low cost meat and dark poultry meat (Akamittath et al., 1990). Various non-meat protein ingredients, including egg proteins, gelatin, milk proteins and soybean proteins such as isolated soy protein (ISP), have been commonly applied to improve the textural properties of restructured meat products (Pietrasik et al., 2007) as well as for the development of low/reduced-fat meat products (Hsu and Sun, 2006). Among these additives, gelatin, as a binder and gelling agent, is extensively used in restructured meat products due to its low melting point and gel formation ability (Boran et al., 2010). Moreover, it has the ability to improve the rheological properties of meat products through interaction with muscle proteins,

\footnotetext{
*Corresponding author: Cheon Jei Kim, Department of Food Science and Biotechnology of Animal Resources, Konkuk University, Seoul 143-701, Korea. Tel: +82-2-450-3684, Fax: +822-444-6695, E-mail: kimcj@konkuk.ac.kr
}

primarily myosin (Yang et al., 2007). Additionally, gelatin has been traditionally used to manufacture cold-cut meat products, such as brawn, headcheese, and meat jelly; further, the ingredients in these meat products are bound together by gelatin or collagen-rich parts, which come from the head, shank and skin via thermal processing (Feiner, 2006; Gómez-Guillén et al., 2011). Among these product, meat jelly has been typically produced from lean meat such as chicken breast, and usually contains salt (final concentration of 1-2\%), nitrite, phosphate, additives including carrageenan and starch, and vinegar which decreases $\mathrm{pH}$ value and forms a sour taste (Feiner, 2006).

Gelatin, which is one of the derived proteins, is generally obtained from collagen in animal tissues, such as cow hide and bone, pork skin, and fish scales; moreover, the functional properties of gelatin are greatly affected by the types of collagen source as well as the extracting condition, including the $\mathrm{pH}$, temperature and time (GómezGuillén et al., 2011). Poultry by-products, mainly the feet and head, have received the most attention as an alternative material of collagen or gelatin. Hence, further research is being carried out in order to obtain more conclusive 
information and effective use of collagen and gelatin produced form poultry by-products. Lim et al. (2002) determined the optimal extracting condition of chicken feet gelatin by using the response-surface methodology, and Kim (2011) reported that chicken feet gelatin could improve the drying yield and decrease the shear force of semi-dried chicken jerky. Recently, Park (2013) reported the optimal condition affecting the quality characteristics of duck feet gelatin soaked in an acidic condition and extracted using various thermal methods. Huda et al. (2013a) concluded that duck feet collagen has similar functional properties to those of surimi, as compared to cow and fish collagens, and therefore suggested that the utilization of duck feet collagen is an effective way to solve poultry waste using the comparative method with commercial fish and cow collagens (Huda et al., 2013b). Along with bird feet, in addition, poultry head has also shown development possibility as a novel gelatin source (Du et al., 2013).

In the last decade, the consumption of duck meat in Korea has been increasing steadily, in 2012, the consumption of duck meat per head of the population in Korea has approached $3.4 \mathrm{~kg}$ (Korea Duck Association, 2013). Coincidentally, the production of duck by-products, including bone, feather, feet and internal organs, is also increasing. In addition, the consumption pattern of duck meat around the world is considerably simple and furthermore, duck by-products are actually underutilized as an edible animal source. Thus, more research is necessary in order to develop novel duck meat products as well as to effectively use duck by-products, including duck feet.

Therefore, the objective of this study was conducted to develop novel duck meat product which is type of coldcut meat product and to evaluate the effects of duck feet gelatin concentration on the physicochemical, textural and sensory properties of meat jellies.

\section{Materials and Methods}

\section{Duck feet gelatin extraction}

Duck feet gelatin was extracted using the modified method of Park (2013) based on acidic swelling and hot water extraction method. Washed duck feet were soaked with five volumes $(\mathrm{v} / \mathrm{w})$ of $0.1 \mathrm{~N} \mathrm{HCl}$ solution (Samchun, Korea) at room temperature for $24 \mathrm{~h}$. The swelled duck feet were neutralized with flowing tap water for $48 \mathrm{~h}$ until $\mathrm{pH}$ 5.5. The sample were vacuum-packaged with polyethylene bags, and then cooked in a $75^{\circ} \mathrm{C}$ water bath for $6 \mathrm{~h}$ to extract duck feet gelatin. The duck feet extracts were filtered using cheese cloth (four layers), and cooled at room temperature. After gelation, fat layer in the top of the duck feet gelatin gel was removed. The duck feet gelatin gel was frozen at $-70^{\circ} \mathrm{C}$ and freeze-dried using freeze dryer $\left(80 \times 10^{-3}\right.$ torr pressure, PVTFD20R, Ilshin lab, Korea). The moisture content of freeze-dried duck feet gelatin powder was below $10 \%$.

\section{Duck feet gelatin gel preparation}

At first, duck feet gelatin gels with four different concentrations $(5,10,15$, and $20 \%, \mathrm{w} / \mathrm{v})$ were prepared to evaluate the effect of duck feet gelatin concentration on sensory properties. The duck feet gelatin powder was dissolved with $75^{\circ} \mathrm{C}$ warm water, and the gelatin solution was stirred for $5 \mathrm{~min}$. Each gelatin solution were cooled in a $4^{\circ} \mathrm{C}$ refrigerator for $24 \mathrm{~h}$, and coagulated gelatin gel was cut into cube size $\left(1 \times 1 \times 1 \mathrm{~cm}^{3}\right)$ and used to determine the sensory properties of duck feet gelatin gel with various concentrations.

\section{Preparation of duck meat jellies}

Fresh duck tenderloin muscles (Musculus pectoralis minor) after post-mortem $48 \mathrm{~h}$ were purchased from a local market. Duck tenderloin was cured with $1.8 \%$ of nitrite pickled salt (NPS) and then kept at $4^{\circ} \mathrm{C}$ in a refrigerator for $24 \mathrm{~h}$. The cured duck meat was vacuum-packaged with polyethylene bags, and then cooked in a $75^{\circ} \mathrm{C}$ water bath for $40 \mathrm{~min}$. The cooked duck meat were cut using silent cutter (Nr-963009, Scharfen, Witten, Germany) within rotation of 2-3 times, and blended with duck feet gelatin powder, water and the other ingredients ( $0.5 \%$ sugar, $0.3 \%$ sodium tripolyphosphate, $0.02 \%$ ascorbic acid, $0.3 \%$ soy sauce, $0.1 \%$ black pepper, $0.2 \%$ garlic powder, $0.03 \%$ mono-sodium ${ }_{\mathrm{L}}$-glutamate, and $1 \%$ lemon juice). This formulation was based on modification of recipe which is introduced by Feiner (2006). In a preparatory experiment, the addition of duck feet gelatin powder under 3\% concentration has not coagulated, for this reason, four different formulations of duck meat jellies are prepared with 3-6\% duck feet gelatin powder; $70 \%$ cured duck breast $+27 \%$ water $+3 \%$ duck feet gelatin powder (T1), $70 \%$ cured duck breast $+26 \%$ water $+4 \%$ duck feet gelatin powder (T2), $70 \%$ cured duck breast $+25 \%$ water + $5 \%$ duck feet gelatin powder (T3), and 70\% cured duck breast $+24 \%$ water $+6 \%$ duck feet gelatin powder (T4). Each mixture was stuffed into non-permeable PVDC casings (Nalo Top, Kalle GmbH, Germany; approximate 60 mm diameter) by using a stuffer (IS-8, Sirman, Marsango, Italy). After stuffing, meat jellies were cooked at $85^{\circ} \mathrm{C}$ water bath for $40 \mathrm{~min}$, and the final core temperature was 
$75^{\circ} \mathrm{C}$. And then, the meat jellies were cooled at $4^{\circ} \mathrm{C}$ for $24 \mathrm{~h}$ to gelation and stored in a $4^{\circ} \mathrm{C}$ refrigerator until analysis.

\section{Sodium dodecyl sulfate-polyacrylamide gel electro- phoresis (SDS-PAGE)}

To confirm the changes in protein patterns of duck meat jellies due to the addition of duck feet gelatin, SDSPAGE of the separated total protein fraction of the duck feet gelatin, duck tenderloin, and duck meat jellies was performed by the method of Laemmli (1970), using 12\% running gels and $5 \%$ stacking gels $(20 \mu \mathrm{L}$ loaded). The loaded gel was stained with Coomassie Brilliant Blue R250 (B7920, Sigma Chemical Co., USA), and was destained in methanol : distilled water : acetic acid system (50:40:10). The separated protein bands were identified by comparison with those of standard protein marker (Precision Plus Protein Standards, Bio-Rad Lab., USA).

\section{Proximate composition}

Proximate composition of duck meat jellies was performed using AOAC (2000). Moisture content was determined by weight loss after $12 \mathrm{~h}$ at $105^{\circ} \mathrm{C}$ in an oven (SW90D, Sang Woo Scientific Co., Korea). Fat content by Soxhlet extraction (Soxtec ${ }^{\circledR}$ Avanti 2050 Auto System, Foss Tecator AB, Sweden) and protein content by an automatic Kjeldahl nitrogen analyzer (Kjeltec ${ }^{\circledR} 2300$ Analyzer Unit, Foss Tecator AB, Höganas, Sweden). Ash was determined according to AOAC method 920.153 (muffle furnace).

\section{Instrumental color evaluation}

Instrumental color of duck meat jellies were determined using a colorimeter (Minolta Chroma meter CR-210, Japan; calibrated with a white plate, CIE $\mathrm{L}^{*}=+97.83$, CIE $\mathrm{a}^{*}=-0.43$, CIE $\mathrm{b}^{*}=+1.98$ ), equipped with a $50 \mathrm{~mm}$ aperture. The setting for the illuminant was $\mathrm{C}$ illuminant source and the observer was standard $2^{\circ}$. One measurement on surface of each meat jelly was taken, and total six measurements were obtained from six locations of each sample. CIE L* (lightness), CIE a* (redness), and CIE b* (yellowness) values were recorded.

\section{Hardness}

Hardness of duck meat jellies was performed in triplicate on each sample at room temperature with a texture analyzer (TA-XT2i, Stable Micro Systems Ltd., England). Each sample was cut into equal shape $(2.5 \mathrm{~cm}$ thickness and $6 \mathrm{~cm}$ diameter) and the sliced duck meat jellies were allowed to equilibrate in a $4^{\circ} \mathrm{C}$ refrigerator to prevent mel- ting gelatin. Samples were taken from the central or edge portion of each duck meat jelly sample. The conditions of texture analysis were as follows: pre-test speed $2.0 \mathrm{~mm} / \mathrm{s}$, post-test speed $5.0 \mathrm{~mm} / \mathrm{s}$, maximum load $2 \mathrm{~kg}$, head speed $2.0 \mathrm{~mm} / \mathrm{s}$, distance $8.0 \mathrm{~mm}$, force $5 \mathrm{~g}$. The calculation of hardness was obtained by graphing a curve using force and time plots.

\section{Sensory evaluation}

The panel consisted of 10 members which were trained following ASTM standards (ASTM, 1981), with a minimum of 6 mon of experience in sensory evaluation on meat products. In terms of the sensory properties of duck feet gelatin gel $(5,10,15$, and $20 \%$ gelatin concentrations), color ( $1=$ extremely undesirable, $10=$ extremely desirable), hardness ( $1=$ extremely hard, $10=$ extremely soft), and dispersibility in mouth (1=badly dispersed, 10=welldispersed) were evaluated (Choi and Regenstein, 2000). The duck meat jellies containing 3, 4, 5, and $6 \%$ duck feet gelatin were evaluated for appearance, color, flavor, texture, and overall acceptance (1=extremely undesirable, 10 $=$ extremely desirable) using a 10-point descriptive hedonic scale. All samples as previously described were cut at room temperature $\left(25^{\circ} \mathrm{C}\right)$ and served to the panelists in random order. The sensory evaluations were performed by the trained panelists under fluorescence lighting. Panelists were instructed to cleanse their palates between samples using warm water.

\section{Statistical analysis}

All tests were done at least three times for each experimental condition and mean values were reported. Oneway ANOVA was employed to determine the significance of main effect (duck feet gelatin level) using the SAS statistical package (2008). Duncan's multiple range test $(p<0.05)$ was used to determine differences between treatment means. The procedure CORR of the SAS package was used to calculate correlations between duck feet gelatin level and the measurements.

\section{Results and Discussion}

\section{Sensory properties of duck feet gelatin gel}

The use of gelatin generally influences the rheological, textural and sensory properties by various foods. In particular, the melting property in the mouth is one of the reasons as to why gelatin is used for manufacturing coldcut meat products and desserts (Choi and Regenstein, 2000). Also, Boran et al. (2010) indicated that the two 


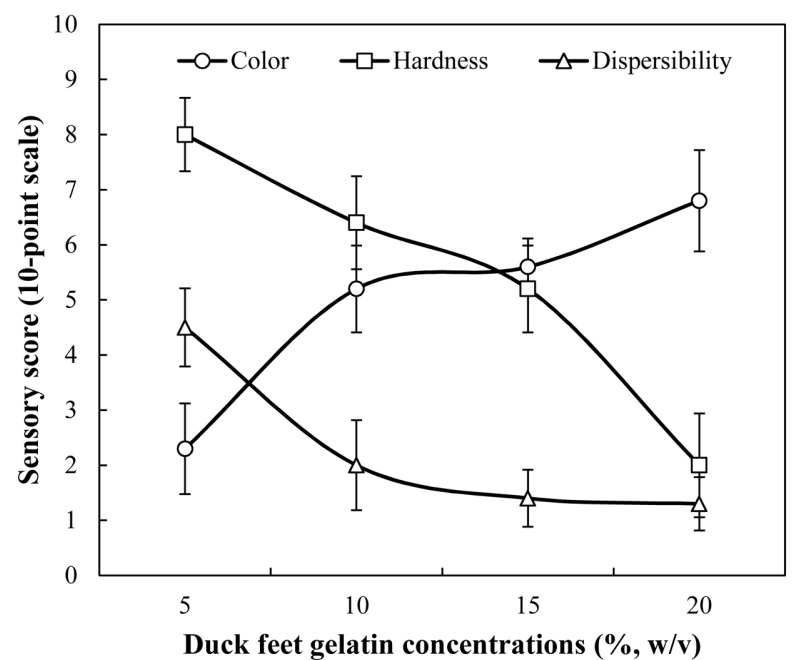

Fig. 1. Changes in sensory properties of duck feet gelatin gel prepared with $5-20 \%$ duck feet gelatin concentration. Color $(\bigcirc)$, hardness $(\square)$, and dispersibility in mouth $(\triangle)$ scores.

major characteristics of gelatin are its low melting point and gel strength. The effect of duck feet gelatin concentration on the sensory properties, including color, texture and dispersion in mouth (dispersibility) of duck feet gelatin gel is presented in Fig. 1. Significant $(p<0.001)$ changes in the sensory properties of duck feet gelatin gel were observed due to the concentration of duck feet gelatin. An increase in duck feet gelatin concentration contributed to improving the color score, but decreasing the hardness and dipersibility satisfaction scores. Similarly, Finney and Meullenet (2005) reported that an increase in the hardness score of bone gelatin (type B) gel was observed with an increasing gelatin concentration that ranged from 8.0 to $23.0 \%$. In a gelatin concentration of $22.5-35.0 \%$ in porcine (type A) and bovine (type B) gelatins, a similar result also reported by Jones et al. (2003). Basically, the gelation of the gelatin solution is generated from the formation of cross-linking between proteinaceous components, which contain the Gly-Pro-Hyp amino acid sequence (Surówka, 1997). In terms of dispersibility, according to Takahashi and Nakazawa (1991), an increase in gelatin concentration led to the increased retention time of gelatin gel in the mouth for swallowing.

\section{Protein pattern (SDS-PAGE) of duck meat jellies}

The effect of duck feet gelatin on the protein patterns of duck meat jellies formulated with $3-6 \%$ is presented in Fig. 2. In duck feet gelatin, three major protein bands, which are expected as $\alpha 1$ and $\alpha 2$ chains (120-130 kDa) and $\beta$ chain $(200 \mathrm{kDa})$, were observed. Also, a trimers

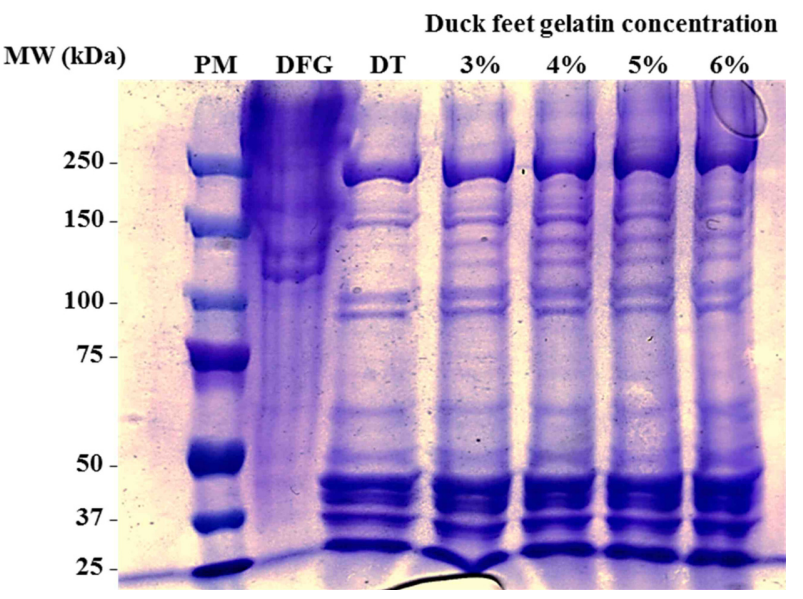

Fig. 2. Sodium dodecyl sulfate-polyacrylamide gel electrophoresis (SDS-PAGE) photographs of proteins from duck feet gelatin (DFG), duck tenderloin (DT), and duck meat jellies formulated with 3-6\% duck feet gelatin. PM, standard protein marker.

molecule (upper $250 \mathrm{kDa}$ ), which is expected as $\gamma$ chain, was observed as well. However, it is hard to ascertain the distinction of these proteins from the other bands in duck meat tenderloin, whereas an increase in the added amount of duck feet gelatin in duck meat jellies clearly resulted in an increased intensity of theses bands. Similarly, Du et al. (2013) reported that gelatin obtained from poultry head, such as turkey and chicken, is composed of $\alpha 1$ and $\alpha 2$ chains along with their dimer ( $\beta$ chain) and trimmers $(\gamma$ chain). According to Park (2013), the protein bands of duck feet gelatin with hot water extraction contain $\alpha 1, \alpha$ 2 and $\beta$ chains, which are derived from type I collagen. Further, their study suggested that the protein patterns of duck feet gelatin are similar to those of chicken feet collagen. Thus, this result obviously confirms that the addition of duck feet gelatin could affect the changes in the protein band patterns of duck meat jellies.

\section{Proximate composition of duck meat jellies}

The effect of duck feet gelatin concentration on the proximate composition of duck meat jellies is shown in Table 1. The moisture content of meat jellies decreased when the added level of duck feet gelatin increased. As expected, the increase in duck feet gelatin level contributed to the increased protein content, and the addition of $6 \%$ duck feet gelatin conveyed an increased protein content of $1.81 \%$ compared to that of meat jelly containing $3 \%$ duck feet gelatin $(p<0.05)$. The fat and ash content ranges of duck meat jellies were $1.75-1.96 \%$ and 0.98 $1.08 \%$, respectively. However, there were no significant differences among all treatments. Similarly, Prabhu et al. 
Table 1. Effect of duck feet gelatin concentration on proximate composition of duck meat jellies

\begin{tabular}{ccccc}
\hline \hline \multirow{2}{*}{ Parameters (\%) } & \multicolumn{4}{c}{ Duck feet gelatin ${ }^{\text {I) }}$ concentration (\%) } \\
\cline { 2 - 5 } & 3 & 4 & 5 & 6 \\
\hline Moisture & $76.37 \pm 0.62^{1) \mathrm{a}}$ & $76.13 \pm 0.20^{\mathrm{a}}$ & $74.62 \pm 1.15^{\mathrm{b}}$ & $74.59 \pm 0.34^{\mathrm{b}}$ \\
Protein & $20.87 \pm 0.06^{\mathrm{c}}$ & $22.01 \pm 0.24^{\mathrm{b}}$ & $22.37 \pm 0.01^{\mathrm{ab}}$ & $22.67 \pm 0.08^{\mathrm{a}}$ \\
Fat & $1.96 \pm 0.35$ & $1.89 \pm 0.21$ & $1.79 \pm 0.17$ & $1.75 \pm 0.30$ \\
Ash & $0.98 \pm 0.03$ & $1.01 \pm 0.07$ & $0.94 \pm 0.02$ & $1.08 \pm 0.15$ \\
\hline
\end{tabular}

${ }^{1)}$ All values are mean \pm standard deviation.

${ }^{\mathrm{a}-\mathrm{c}}$ Means within a row with different letters are significantly different $(p<0.05)$.

Table 2. Effect of duck feet gelatin concentration on color characteristics of duck meat jellies

\begin{tabular}{ccccc}
\hline \hline Parameters & \multicolumn{4}{c}{ Duck feet gelatin ${ }^{\text {I) }}$ concentration (\%) } \\
\cline { 2 - 5 } & 3 & 4 & 5 & 6 \\
\hline CIE L* $^{*}$ & $58.38 \pm 0.66^{1) \mathrm{a}}$ & $57.72 \pm 0.84^{\mathrm{a}}$ & $57.11 \pm 0.52^{\mathrm{b}}$ & $56.32 \pm 0.38^{\mathrm{c}}$ \\
CIE a* $_{\text {CIE b* }}$ & $14.64 \pm 1.17$ & $14.42 \pm 0.78$ & $14.43 \pm 0.44$ & $14.29 \pm 0.81$ \\
\end{tabular}

${ }^{1)}$ All values are mean \pm standard deviation.

${ }^{a-c}$ Means within a row with different letters are significantly different $(p<0.05)$.

(2004) noted that the differences in protein content of frankfurters or whole muscle hams formulated with pork collagen ranging from 0 to $3 \%$ were $1.67 \%$ or $2.13 \%$, respectively. However, there were no significant differences in the fat and ash contents among all treatments. In addition, Hsu and Sun (2006) noted that the emulsified meatball added with $4 \%$ gelatin had lower moisture content and higher protein content compared to the low-fat emulsified meatball. In this study, the protein content of duck feet gelatin is $88.5 \%$ (data not shown), and based on the formulation in this study, the increase in the added level of duck feet gelatin led to the increased protein content of duck meat jellies.

\section{Color characteristics of duck meat jellies}

The effect of duck feet gelatin concentration on the color characteristics of duck meat jellies is shown in Table 2. An increase in the added amount of duck feet gelatin contributed to a decrease in the CIE $\mathrm{L}^{*}$ value (lightness) of duck meat jellies. Also, the addition of duck feet gelatin above $5 \%$ showed lower lightness $(p<0.05)$ than those of duck meat jellies prepared with 3-4\% duck feet gelatin. However, there were no significant differences in the CIE $a^{*}$ value (redness) and $b^{*}$ value (yellowness) of duck meat jellies regardless of the difference of duck feet gelatin concentration ( $p>0.05)$. According to Huda et al. (2013a), the addition of duck feet collagen led to an increase ( $p<$ 0.05 ) in all color parameters, including lightness, redness and yellowness, compared to those of surimi gels prepared with white flesh (threadfin bream) or dark-flesh (sardine) fishes, respectively. Meanwhile, Ahmad and Benjakul (2011) indicated that the prolonged extraction time dec- reased the lightness of gelatin due to the Maillard reaction. The lightness of duck feet gelatin powder in this study is 70.22 , which is lower than that of duck feet collagen powder (CIE L* value, 86.98), as reported by Huda et al. (2013b). Thus, the decrease in the lightness of duck meat jellies by adding duck feet gelatin could be ascribed by a color characteristic of duck feet gelatin.

\section{Hardness of duck meat jellies}

The effect of duck feet gelatin concentration on the hardness in the center and edge of duck meat jellies is shown in Fig. 3. The statistical result revealed a significantly linear effect of duck feet gelatin on the hardness of duck meat jellies. Moreover, the increase in the added amount of duck feet gelatin is highly correlated with the hardness in the center $\left(p<0.01, R^{2}=0.91\right)$ and the edge ( $p<$ $0.01, R^{2}=0.89$ ) of duck meat jellies. The hardness in the center of meat jellies was significantly higher $(p<0.05)$ than that in the edge regardless of the duck feet gelatin concentration. A similar result was reported by Hsu and Sun (2006) as well, who noted that low-fat emulsified meat ball prepared with $4 \%$ gelatin had a significantly higher hardness than the high-fat control. In general, the gelation of meat products after thermal processing is produced by the formation and interaction of muscle proteins, including myofibrillar protein (salt-soluble), sarcoplasmic (water-soluble) and connective tissue, or mainly collagen. Among these, collagen is completely solubilized at $74-80^{\circ} \mathrm{C}$, and solubilized collagen is denatured to gelatin thereby contributing to the texture formation, such as hardness, gumminess and chewiness of meat products (Brewer et al., 2005). For these reasons, collagen and gel- 


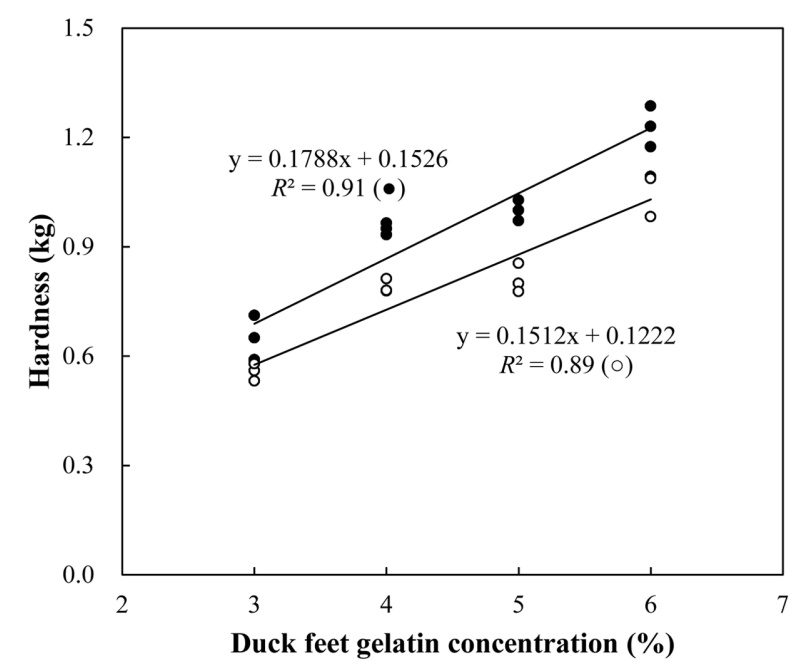

Fig. 3. Hardness in the center $(\bullet)$ and edge $(O)$ of duck meat jellies formulated with various duck feet gelatin concentrations.

atin have been extensively used as a gelling agent for improving the textural properties in various meat products (Meullenet et al., 1994; Pereira et al., 2011; Prabhu et al., 2004). Interestingly, Doerscher et al. (2004) indicated that pure myofibrillar protein and pork collagen had no their protein interaction, and therefore suggested that the inclusion of pork collagen within $10 \%$, which is a non-interacting ratio for generating myofibrillar heat induced gel, could improve the yield and textural properties due to the gel forming ability of collagen during cooling. Additionally, Brewer et al. (2005) noted that an increase in pork skin gelatin concentration (1-12\%) led to the formation of hard texture of gelatin gel. In the heat-induced gel prepared with myofibrillar protein (6-12\%) and pork skin gelatin (6-12\%), the addition of gelatin enhanced the decreased hardness resulting from the decrease of the myofibrillar protein. Thus, duck feet gelatin forms heat reversible gel and the formed gel could immobilizes meat particles after cooking. These two effects could result in the firm texture of duck meat jellies.

\section{Sensory properties of duck meat jellies}

The effect of duck feet gelatin concentration on the sensory properties of duck meat jellies is shown in Table 3 . The increase of duck feet gelatin in duck meat jellies resulted in a high satisfaction score of appearance; the addition of duck feet gelatin above $5 \%$ indicated the highest appearance score $(p<0.05)$. In terms of texture, however, the increase in duck feet gelatin caused a decline in the score for texture satisfaction; further, duck meat jellies containing $6 \%$ duck feet gelatin had a significantly lower texture satisfaction score than those containing 3\% duck feet gelatin $(p<0.05)$. Previously, Prabhu et al. (2004) reported that a panelist could significantly realize the sensorial differences of frankfurters formulated with $2.5 \%$ pork collagen and above as compared to frankfurters without pork collagen. In this study, the highest score for the overall acceptance was observed for duck meat jellies formulated with 5\% duck feet gelatin. In addition, a significant difference in the overall acceptance of duck meat jellies formulated with $5 \%$ duck feet gelatin was observed as compared to those prepared with $3 \%$ duck feet gelatin $(p<0.05)$. Consequently, the optimal level of duck feet gelatin for contributing to the high satisfaction in the sensory evaluation was determined as $5 \%$. Hence, this effect might be greatly associated with the formation of durable appearance and suitable texture of duck meat jellies.

\section{Correlation between duck feet gelatin level and measurements}

The coefficients of correlation for duck meat jellies formulated with 3-6\% duck feet gelatin are presented in Table 4. The relationships between duck feet gelatin concentration and hardness in both the center and the edge were highly significant $(p<0.01)$ and therefore, the correlations showed high positive values $(\mathrm{r}=0.96$ and $\mathrm{r}=0.95$,

Table 3. Effect of duck feet gelatin concentration on sensory properties of duck meat jellies

\begin{tabular}{|c|c|c|c|c|}
\hline \multirow{2}{*}{ Traits $^{1)}$} & \multicolumn{4}{|c|}{ Duck feet gelatin concentration (\%) } \\
\hline & 3 & 4 & 5 & 6 \\
\hline Appearance & $6.90 \pm 0.32^{2) c}$ & $7.60 \pm 0.52^{b}$ & $8.40 \pm 0.52^{\mathrm{a}}$ & $8.40 \pm 0.52^{\mathrm{a}}$ \\
\hline Color & $8.10 \pm 0.88$ & $8.40 \pm 0.70$ & $8.50 \pm 0.53$ & $8.30 \pm 0.48$ \\
\hline Flavor & $7.30 \pm 0.48$ & $7.50 \pm 0.71$ & $7.70 \pm 0.48$ & $7.90 \pm 0.99$ \\
\hline Texture & $8.40 \pm 0.84^{\mathrm{a}}$ & $8.30 \pm 0.82^{\mathrm{A}}$ & $8.10 \pm 0.74^{\mathrm{ab}}$ & $7.50 \pm 0.85^{b}$ \\
\hline Juiciness & $7.70 \pm 0.95$ & $7.70 \pm 0.95$ & $7.90 \pm 0.88$ & $7.30 \pm 0.95$ \\
\hline Overall acceptance & $7.20 \pm 0.79^{\mathrm{b}}$ & $7.60 \pm 0.52^{\mathrm{ab}}$ & $8.10 \pm 0.88^{\mathrm{a}}$ & $7.70 \pm 0.95^{\mathrm{ab}}$ \\
\hline
\end{tabular}

${ }^{1)}$ Traits: $1=$ extremely undesirable, $10=$ extremely desirable

${ }^{2)}$ All values are mean \pm standard deviation.

${ }^{\mathrm{a}-\mathrm{c}}$ Means within a row with different letters are significantly different $(p<0.05)$. 
Table 4. Coefficients of correlation between duck feet gelatin concentration and measurements of duck meat jellies

\begin{tabular}{cc}
\hline \hline Parameters & Correlation coefficient (r) \\
\hline Hardness (in the center) & $0.955^{* *}$ \\
Hardness (in the side) & $0.945^{* *}$ \\
Sensory properties & \\
Appearance & $0.769^{* *}$ \\
Color & $0.121^{\mathrm{NS}}$ \\
Flavor & $0.319^{\mathrm{NS}}$ \\
Texture & $-0.382^{*}$ \\
Juiciness & $-0.123^{\mathrm{NS}}$ \\
Overall acceptance & $0.272^{\mathrm{NS}}$ \\
\hline
\end{tabular}

${ }^{\mathrm{NS}}$ no-significance; ${ }^{*} p<0.05,{ }^{* *} p<0.01$.

respectively). The relationship between duck feet gelatin concentration and appearance was highly significant as well $(p<0.01, r=0.77)$. As aforementioned, although there were significant differences in the texture and overall acceptance among treatments, the result of these parameters were not linearly related to duck feet gelatin concentration. Thus, the significant relationship between duck feet gelatin concentration and sensory properties, such as texture and overall acceptance, was not observed $(p>0.05)$.

In conclusion, duck meat jellies as a cold-cut meat product were successfully manufactured using duck feet gelatin and duck tenderloin. Within the duck feet gelatin concentration of $3-6 \%$, the increase in the added amount of duck feet gelatin has major positive effects on the increase in the protein content. In the textural properties, the addition of duck feet gelatin consistently increased the hardness in the center and edge of the duck meat jellies; however, the sensory satisfaction for the texture had no linear relationship with the duck feet gelatin concentration. Therefore, duck feet gelatin is a useful ingredient for manufacturing cold-cut meat products, considering the sensory acceptance, the optimal level of duck feet gelatin in duck meat jellies was determined as $5 \%$.

\section{Acknowledgements}

This research was supported (111027-02-1-HD110) by the Rural Development Administration (Republic of Korea). The authors were supported by the Brain Korean 21 Plus (BK 21 Plus) Project from Ministry of Education and Human Resources Development.

\section{References}

1. Ahmad, M. and Benjakul, S. (2011) Characteristics of gela- tin from the skin of unicorn leatherjacket (Aluterus monoceros) as influenced by acid pretreatment and extraction time. Food Hydrocolloid. 25, 381-388.

2. Akamittath, J. G., Brekke, C. J., and Schanus, E. G. (1990) Lipid oxidation and color stability in restructured meat systems during frozen storage. J. Food Sci. 55, 1513-1517.

3. AOAC (2000) Official methods of analysis. 17th ed, Association of Official Analytical Chemists, Washingotn, DC, USA.

4. ASTM (1981) American Society for Testing and Materials. Guidelines for the selection and training of sensor and panel members. ASTM STP 758, ASTM Philadelphia, 3-33.

5. Boran, G., Mulvaney, S. J., and Regenstein, J. M. (2010) Rheological properties of gelatin from silver carp skin compared to commercially available gelatins from different sources. $J$. Food Sci. 75, E565-E571.

6. Brewer, M. S., Peterson, W. J., Carr, T. C., Mccusker, R., and Novakofski, J. (2005) Thermal gelation properties of myofibrillar protein and gelatin combinations. J. Muscle Food 16, 126-140.

7. Choi, S. S. and Regenstein, J. M. (2000) Physicochemical and sensory characteristics of fish gelatin. J. Food Sci. 65, 194199.

8. Doerscher, D. R., Briggs, J. L., and Lonergan, S. M. (2004) Effects of pork collagen on thermal and viscoelastic properties of purified porcine myofibrillar protein gels. Meat Sci. 66, 181-188.

9. Du, L., Khiari, Z., Pietrasik, Z., and Betti, M. (2013) Physicochemical and functional properties of gelatins extracted from turkey and chicken heads. Poult. Sci. 92, 2463-2474.

10. Feiner, G. (2006) Meat product handbook: Practical science and technology. 1st ed, CRC Press, NY, pp. 519-529.

11. Finney, M. and Meullenet, J. F. (2005) Measurement of biting velocities at predetermined and individual crosshead speed instrumental imitative tests for predicting sensory hardness of gelatin gels. J. Sens. Stud. 20, 114-129.

12. Gómez-Guillén, M. C., Giménez, B., López-Caballero, M. E., and Montero, M. P. (2011) Functional bioactive properties of collagen and gelatin from alternative sources: A review. Food Hydrocolloid. 25, 1813-1827.

13. Hsu, S. Y. and Sun, L. Y. (2006) Comparisons on 10 non-meat protein fat substitutes for low-fat Kung-wans. J. Food Eng. 74, 47-53.

14. Huda, N., Seow, E. K., Normawati, M. N., and Nik Aisyah, N. M. (2013b) Preliminary study on physicochemical properties of duck feet collagen. Int. J. Poult Sci. 12, 615-621.

15. Huda, N., Seow, E. K., Normawati, M. N., Nik Aisyah, N. M., Fazilah, A., and Easa, A. M. (2013a) Effect of duck feet collagen addition on physicochemical properties of surimi. Int. Food Res. J. 20, 537-544.

16. Jones, R. R., Steffe, J. F., and Harte, J. B. (2003) Sensory firmness scale based on gelatin gels. J. Texture Stud. 33, 543558.

17. Kim, H. Y. (2011) Utilization of wheat fiber chicken skin and feet hydrolyzates as a binder of extender in chicken meat products. Ph.D. thesis, Konkuk Univ., Seoul, Korea.

18. Korea Duck Association. Available from: http://www.korea- 
duck.org/sub/statistics_3_7.asp?mNum=3\&sNum=3\&p=7. Accessed Mar. 9, 2014.

19. Laemmli, U. K. (1970) Cleavage of structural proteins during the assembly of the head of bacteriophage T4. Nature 227, 680-685.

20. Lim, J., Shin, W. S., Lee, H. G., and Kim, K. O. (2002) Optimizing extraction conditions for chicken feet gelatin. Korean J. Food Sci. Technol. 34, 824-829.

21. Meullenet, J. F., Chang, H. C., Carpenter, J. A., and Resurreccion, A. V. A. (1994) Textural properties of chicken frankfurters with added collagen fibers. J. Food Sci. 59, 729-733.

22. Park, J. H. (2013) Functional characterization of gelatin extracted from duck feet and its utilization. Master's thesis, Konkuk Univ., Seoul, Korea.

23. Pereira, A. G. T., Ramos, E. M., Teixeira, J. T., Cardoso, G. P., Ramos, A. L. S., and Fontes, P. R. (2011) Effects of the addition of mechanically deboned poultry meat and collagen fibers on quality characteristics of frankfurter-type sausage. Meat Sci. 89, 519-525.
24. Pietrasik, Z., Jarmouluk, A., and Shand, P. J. (2007) Effect of non-meat proteins on hydration and textural properties of pork meat gels enhanced with microbial transglutaminase. LWTFood Sci. Technol. 40, 915-920.

25. Prabhu, G. A., Doerscher, D. R., and Hull, D. H. (2004) Utilization of pork collagen protein in emulsified and whole muscle meat products. J. Food Sci. 69, C388-C392.

26. SAS (2008) SAS/STAT Software for PC. Release 9.2, SAS Institute Inc., Cary, NC, USA.

27. Surówka, K. (1997) Effect of protein hydrolysate on the instrumental texture profile of gelatin gels. J. Texture Stud. 28, 289-303.

28. Takahashi, J. and Nakazawa, F. (1991) Palatal pressure patterns of gelatin gels in the mouth. J. Texture Stud. 22, 1-11.

29. Yang, Y. L., Zhou, G. H., Xu, X. L., and Wang, Y. (2007) Rheological properties of myosin-gelatin mixtures. J. Food Sci. 72, C270-C275.

(Received 2014.3.26/Revised 2014.6.2/Accepted 2014.6.2) 